\title{
FISH PRODUCTION ESTIMATES FOR GBEDIKERE LAKE, BASSA, KOGI STATE, NIGERIA
}

\section{Samuel Olusegun Adeyemi}

Department of Biological Sciences, Faculty of Natural Sciences, P.M.B.1008, Kogi State University, Anyigba, Kogi State, Nigeria Corresponding Author, E-mail: sadeyemi2003@yahoo.com

\section{ARTICLE INFO}

Received: 16 November 2012

Received in revised form: 11 April 2013

Accepted: 15 May 2013

Available online: 6 July 2013
Keywords:

Gbedikere Lake

Fish productions

Catch assessment

Fishermen

Fish landings

Fish yield

\begin{abstract}
Annual estimates of the fish caught by local fishermen in randomly selected fishing villages adjacent to Gbedikere Lake were determined using Catch Assessment (CAS). The studies were carried out within two seasons of low water (February) and high water (September) periods between 2006 and 2008. Annual fish catch varied from $537.4 \mathrm{mts}$ to $576.9 \mathrm{mts}$ at high water. Mean catch per boat ranged from $7.40 \mathrm{~kg}$ to $10.60 \mathrm{~kg}$ among the landing sites. A total of 12 fish species were identified belonging to ten families. The catches were dominated by cichlids with Orechromis niloticus dominating the overall catch compositions. Production estimate was compared with the catches obtained through experimental gill-net sampling and potential fish yield estimates using Ryder's Morpho - Edaphic Index (MEI) as modified by Henderson and Welcomme (1974). Contributions of the gears in use were also done with cast nets ranking above others $(29 \%)$, followed by the set net $(25 \%)$, hook and lines $(16.6 \%)$, traps $(16.6 \%)$, clap net $(8.3 \%)$. Management measures were suggested.
\end{abstract}

\section{INTRODUCTION}

Lakes are invaluable ecological resources that serve many human needs and, therefore, enhance our lives by providing a lot of opportunities. This explains why a large proportion of Nigeria population lives near water bodies such as lakes, reservoirs, rivers, swamps and coastal lagoons. Many depend heavily on the resources of such water bodies as their main source of animal protein and family income (Haruna et al., 2006).

Catch Assessment Surveys (CAS) are conducted to obtain reliable current estimates of the total quantity of the fish harvested by fishers. Species composition and fishing effort involved in the catch are considered as secondary objectives while frame surveys among other things provide reliable estimates of changes in the size and structure in the fishing industry over time. Bazigos (1972) studied the yield pattern at Kainji Lake using CAS just as Moses et al. (2002) also used catch assessment meth- od to estimate catches for the artisanal fisheries of south-eastern Nigeria.

CAS could also reveal whether a lake has been overfished or is being underfished. Coulter (1988) found that Lake Tanganyika was underfished in his assessment of the pelagic fish biomass of the lake. Ryder and Henderson (1975) also estimated the potential fish yield for Nasser Reservoir in Egypt using catch assessment and found little evidence to support overexploitation of the stock.

This study describes the fish production in five communities located along the shores of Gbedikere Lake, as well as the contribution of various gears employed for fishing.

\section{MATERIALS AND METHODS}

Frame surveys were carried out involving the count of all the fishing villages, number of fishermen, boats and fishing gears after the methods described in Apeloko and du Feu (1995) and Bankole and 
Mbagwu (2000). Physico-chemical parameters for the lake were obtained using standardized methods as given in APHA (1980). Fish production was estimated using CAS (Bankole and Mbagwu, 2000).

The catch assessment surveys were carried out six times. These were conducted in 3 randomly selected villages among the ones identified from the frame survey. Daily records of catches for six fishermen for 3 days each were obtained once for a low water period and a high water period of 1998, 1999 and 2000. This was done to determine fish abundance by species, weight, catch per boat and overall fish production for the entire lake as stated earlier.

Production estimate was compared with catches obtained through experimental gill-net sampling, as well as potential fish yield estimates using Ryder's Morpho-Edaphic Index (MEI) as modified by Henderson and Welcomme (1974) using conductivity, Toews and Griffith (1979) using conductivity and Schlesinger and Regier (1982) using Total Dissolved Solids (TDS) in the MEI models. These are given by:

(1) Henderson and Welcomme (1974)

$Y=14.3136 M E I^{0.4681}$

Where MEI is $\frac{\text { Conductivity }}{\text { Mean Depth }}$ or $\frac{\text { Total Dissolved Solids }}{\text { Mean Depth }}$

(2) Toews and Griffith (1979)

$\log Y=1.4071+0.3697 \log M E I-0.00004565 A_{0}$ Where $A_{0}=$ Lake area in $\mathrm{km}^{2}$

(3) Schlesinger and Regier (1982)

$\log Y=0.050 T_{\mathrm{m}}+0.280 \log M E I+0.236$

Where $T_{\mathrm{m}}=$ Mean Temperature.

\section{RESULTS}

Physical and chemical parameters of Gbedikere Lake are provided in Table 1 and 2. Water quality parameters of temperature, $\mathrm{pH}$, oxygen, conductivity, total dissolve solids and transparency showed that the lake exhibits a nutrient fair system.

The fish landing identified around Gbedikere Lake was Biroko, being the only location where all the fishermen landed their respective catches. Generally, fewer numbers of fishers and boats were recorded between 2006 and 2008.

Fishers' population was 55, 50 and 48 in 2006, 2007 and 2008, respectively (Table 3). This shows a declining trend. The general decline could be attributed to the tenancy nature of the lake coupled with the migratory nature of the fishers. The fishers are constantly on fishing migration when informed of an improved fishing ground. The lake (6.75 ha) is grossly underexploited with only one fisherman given the $1^{1 / 2}$ or 2 fishermen per $\mathrm{km}^{2}$ recommendation by Henderson and Welcomme (1974).

Table 1. Physical characteristic of Gbedikere lake (ADP, 1995)

\begin{tabular}{lc}
\hline \hline PARAMETER & VALUE \\
\hline Average annual run - off $\left(\mathrm{m}^{3}\right)$ & $1.50 \times 1.0^{8}$ \\
Type of lake & Natural lake \\
Crest elevation $(\mathrm{m})$ & 31.50 \\
Crest length $(\mathrm{m})$ & 1.0 \\
Dead storage level (mAMSL) & 50 \\
Top width $(\mathrm{m})$ & 4.50 \\
Maximum base width $(\mathrm{m})$ & 15.0 \\
Maximum height $(\mathrm{m})$ & 1.50 \\
Total storage capacity $\left(\mathrm{m}^{3}\right)$ & $0.50 \times 1.0^{8}$ \\
Dead storage capacity $\left(\mathrm{m}^{3}\right)$ & $1.50 \times 1.0^{6}$ \\
Active storage capacity $\left(\mathrm{m}^{3}\right)$ & $0.70 \times 1.0^{8} @ 50 \mathrm{~m}$ AMS \\
Surface Area $(\mathrm{ha})$ & 6.75 \\
Spillway width $(\mathrm{m})$ & $0.70 \times 2$ \\
Spillway level $(\mathrm{m})$ & 50.10 \\
Spillway type & Free flow \\
Mean depth $(\mathrm{m})$ & $12.00-15.00$ \\
\hline \hline
\end{tabular}

Table 2. Monthly water quality parameters for Gbedikere Lake from 2006 to 2008

\begin{tabular}{lcc}
\hline \hline Parameter & Mean \pm sd & Range \\
\hline Surface Water Temperature ${ }^{\circ} \mathrm{C}$ & $27.50 \pm 0.05$ & $26.00-29.00$ \\
$\mathrm{pH}$ & $6.55 \pm 0.12$ & $5.08-8.02$ \\
Conductivity $(\mu \mathrm{mhos} / \mathrm{cm})$ & $14.07 \pm 11.08$ & $0.04-49.19$ \\
Dissolved Oxygen $\left(\mathrm{DO}_{2}\right) \mathrm{mgL}^{-1}$ & $8.65 \pm 1.08$ & $6.10-19.85$ \\
Total Dissolved Solid (TDS) & $19.33 \pm 10.09$ & $13.00-45.00$ \\
$\mathrm{mgL}^{-1}$ & $26.60 \pm 8.17$ & $8.00-68.7$ \\
\hline Water Transparency $(\mathrm{cm})$ & & \\
\hline \hline
\end{tabular}

In the fishermen's landings fish from 10 families were recorded. These include Osteoglossidae, Heterotis niloticus (Linnaeus, 1762); Cichlidae, Oreochromis niloticus (Linnaeus, 1758) and Tilapia zilli (Gervais, 1848); Clariidae, Heterobranchus bidorsalis (Geoffrey Saint - Hilaire, 1809; Citharnidae, Citharinus citharus (Geoffrey Saint - Hilaire, 1809); Gymnarchidae, Gymnarchus niloticus (Linnaeus, 1758); Protopteridae, Protopterus annectens (Owen, 1883); Mochokidae, Synodontis nigrita (Valenciennes, 1840); Clariidae, Clarias gariepinus (Burchell, 1822); Cyprinidae, Labeo senegalensis; Mormyridae, Mormyrus rume (Valenciennes, 1846); and Malapteruridae Malapterurus electricus (Gmeiin, 1789).

The highest fish landing was $21,721.5 \mathrm{~kg}$ recorded in January 2007, 21,655.4 kg in February 2007 and $20,216.3 \mathrm{~kg}$ in December 2006. These form 38.6\%, $38.5 \%$ and $35.9 \%$, respectively. Cichlidae dominated the catches constituting $30.91 \%$, followed by $H$. niloticus $(15.56 \%)$ and C. gariepinus (13.16\%), while 
Table 3. Frame assessment result showing the distribution of fishermen's boats and gears along the shores of Gbedikere Lake in September 2006, 2007 and 2008

\begin{tabular}{|c|c|c|c|c|c|c|c|c|c|c|c|c|}
\hline \multirow{3}{*}{$\begin{array}{l}\text { Landing } \\
\text { site }\end{array}$} & \multirow{3}{*}{$\begin{array}{l}\text { Type of fishing } \\
\text { village }\end{array}$} & \multicolumn{6}{|c|}{ No. of fishermen } & \multicolumn{5}{|c|}{ Types of gears } \\
\hline & & \multicolumn{3}{|c|}{ Boat owners } & \multicolumn{3}{|c|}{ Assistants } & \multirow[t]{2}{*}{ Cast net } & \multirow[t]{2}{*}{ Set net } & \multirow[t]{2}{*}{ Hook and line } & \multirow[t]{2}{*}{ Traps } & \multirow[t]{2}{*}{ Clap nets } \\
\hline & & 2006 & 2007 & 2008 & 2006 & 2007 & 2008 & & & & & \\
\hline \multirow[t]{5}{*}{ Biroko } & Village & 5 & 3 & 3 & 10 & 7 & 7 & $x$ & - & $x$ & - & - \\
\hline & Fishing camp & 5 & 3 & 2 & 11 & 9 & 10 & $x$ & $x$ & $x$ & $x$ & - \\
\hline & Fishing camp & 5 & 2 & 3 & 12 & 10 & 9 & $x$ & $x$ & - & - & - \\
\hline & Village & 4 & 3 & 3 & 12 & 12 & 11 & $x$ & - & $x$ & $x$ & - \\
\hline & Village & 4 & 3 & 2 & 10 & 12 & 11 & $x$ & $x$ & - & $x$ & $x$ \\
\hline Total & & & & & 55 & 50 & 48 & & & & & \\
\hline
\end{tabular}

Table 4. Estimated landings ( $\mathrm{kg}$ ) from fishermen's catches for Gbedikere Lake for the low water period of 2006 -2007, February 2008

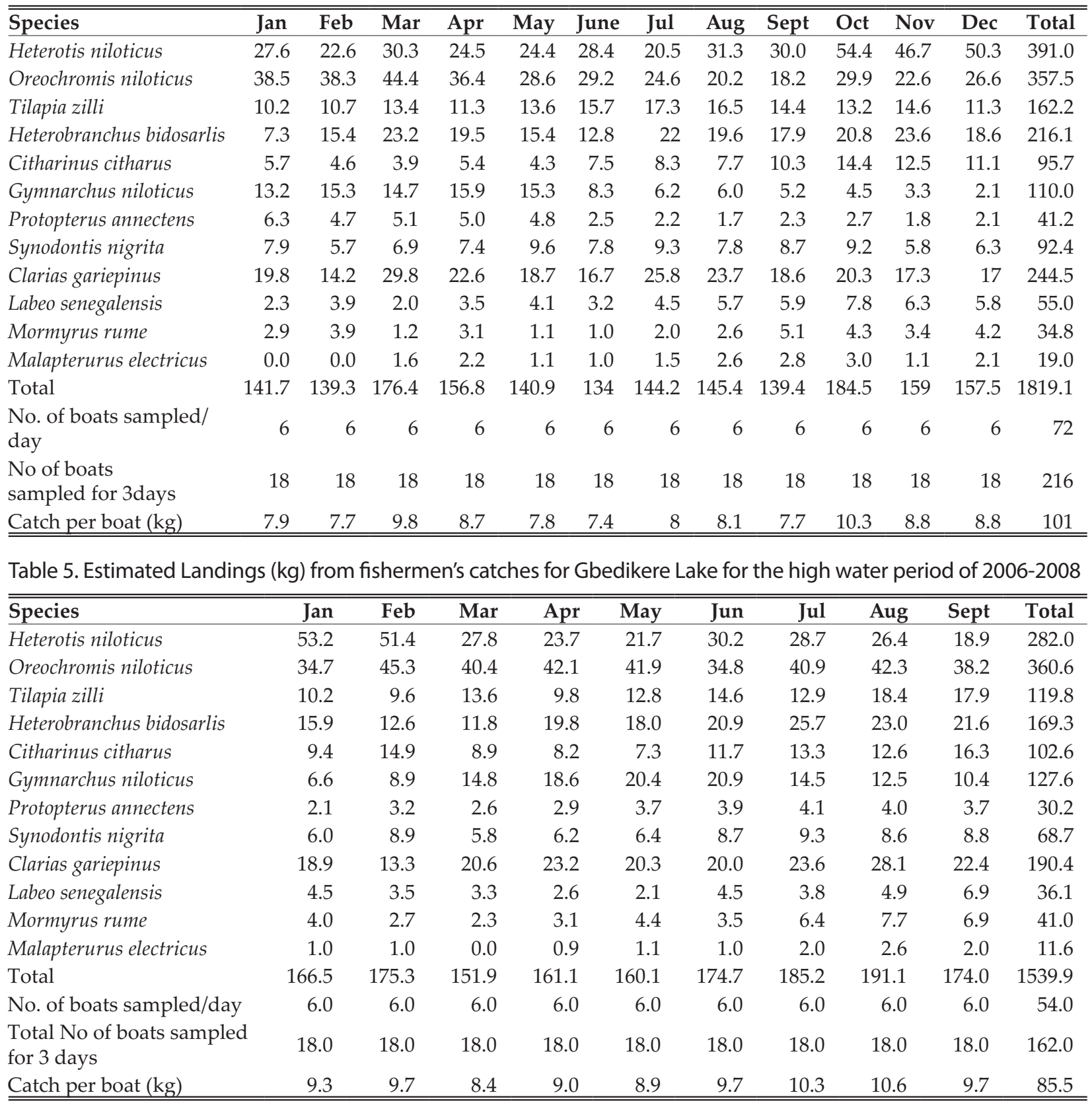


the rest altogether form $40.37 \%$. The mean catch per month was $24.4 \%$ for Gbedikere Lake (Table 4 and 5).

Estimated landings for the whole lake during the low water period were $11.913 .3 \mathrm{mts}$ of fish, recorded in 2006. This declined to $6.449 .2 \mathrm{mts}$ in 2007 and 2008 . For the high water periods the estimated landings were $7.580 .3 \mathrm{mts}$ in 2007, followed by 6.923 .2 $\mathrm{mts}$ in 2008. In general, about the same amount of fish seemed to have been landed for both periods. These are evident in the mean catches for both 537.4 $\mathrm{mts}$ for low water and $576.9 \mathrm{mts}$ for high water. A closer observation reveals that the trend for low water (February) showed a steady decline. The landing for low water of 2007 was $2165.5 \mathrm{mts}$, while in 2008 it was $1000.1 \mathrm{mts}$. These show a decline from $27.3 \%$ to $14.8 \%$, respectively. The trend for high water (September) showed a sharp decline between 2006 and 2008. The trend is $16.6 \%$ in 2006 to $15.8 \%$ decline in 2008 due to poor catches within this period. Generally, small sized fish were caught at this time which could be attributed to growth overfishing. Growth overfishing occurs when the effort is so high that the total yield decreases with increasing effort. Thus the fish are caught before they can grow to a sufficiently large size that can substantially contribute to the fishery. Thus the mean annual yield obtained through Catch Assessment Surveys during the study was $240.2 \mathrm{mts}$. Catch per unit of effort was $24.4 \mathrm{~kg} \mathrm{ha}^{-1}$ for the experimental gillnets. Estimated total catch from the experimental gillnets was 326.6 metric tons.

\section{DISCUSSION}

The result shows that the lake is overfished based on the statistics recorded for the year 2006, 2007 and 2008, as well as low fish catch. Catches are lower both quantitatively and qualitatively. This general decline observed in fish abundance on the lake could thus be attributed to the declining fish catch coupled with the declining number of fishermen. The fishermen are constantly on the move once they receive information about improved catches anywhere; they migrate to such a new 'greener pasture'. Reproduction is very vital to the sustenance, replenishment and progeny maintenance of every living organism. Fish stock is a renewable natural resource which gets replenished from incessant cropping by fishermen through reproduction. The conversation and survivability of any fish species depend more importantly on its reproductive potential. The Gbedikere Lake species are exposed to a daily vigorous harvesting regime by the fishermen. Yet the fish stock had been able to sustain itself even in the face of such onslaught through its resilience. This resilience is made possible through its reproduction potentials.

The number of fishermen recorded for the lake varied from 48-50. This is more than expected; the reservoir with a surface area of $9.6 \mathrm{~km}^{2}$ ought not to have more than 1 fisherman at the recommended rate of 2 fishermen per square kilometer (Henderson and Welcomme, 1974).

The yield result obtained from experimental gill net catches was observed to constitute above $60 \%$ of the landings by all gears on the lake pooled together.

Thus the landings on the lake could be in the range of 326.6 metric tons of fish. This is not far from the overall mean landing of 240.2 metric tons obtained from CAS. It could therefore be said that the fish landing on the lake could be between 300 and 400 metric tons. This would fetch the lake a modest estimate of $\mathrm{N} 24,000,000.00 \mathrm{yr}^{-1}$ at the rate of N80.00 per kg of fish. This is much lower than the earlier estimates of $870 \mathrm{mt} \mathrm{yr}^{-1}$ obtained in Bankole and Mbagwu (2000). However, this production is more than the predicted potentials obtained using the various predictive models above. In a similar study around the southeastern area of Nigeria, Moses et al. (2002) obtained a mean catch per boat of over $6000 \mathrm{~kg}$ from the artisanal fisheries. However, the study by Moses et al (2002) covered a much wider area and included tributaries of major rivers.

The catches on Gbedikere Lake showed a dominance of cichlids, particularly T. zillii and O. niloticus. These were followed by H. niloticus and C. gariepinus in abundance. Apart from the C. gariepinus that reflected promising sizes, the catches generally showed small sized fish, even though most of the species could attain bigger sizes.

To conserve the fish resources, there is the need for intervention through enforcement of the state fishery edict, especially in the area of harvesting small sized (juvenile) fish. This could be done through a community based management approach. This approach will engender/involve a close cooperation among the stakeholders, i.e. the government of the state, the fisher folks and the local community. Once this cooperation is achieved it would be easier to manage the fishery at a sustainable level and the anticipated contribution of the lake to the fish production of the North Centre zone of Nigeria would be achieved. 


\section{Sažetak}

\section{PROCJENA PRODUKCIJE RIBA U JEZERU GBEDIKERE (BASSA, DRŽAVA KOGI, NIGERIJA)}

Godišnja procjena ulova lokalnih ribara za slučajno odabrana ribarska sela iz obližnjeg jezera Gbedikere izvršena je CAS metodom. Istraživanja su provedena u dvama razdobliima tijekom niskog vodostaja (u veljači) i visokog vodostaja (u rujnu) u periodu od 2006. do 2008. godine.

Godišnji ulov kretao se između 537,5 t i 576,9 t pri visokom vodostaju. Prosječan ulov po ribarskom brodu kretao se od 7,4 kg do 10,6 kg između mjesta iskrcaja. Ukupno je identificirano 12 vrsta koje pripadaju u 10 porodica. U ulovu su dominirale vrste iz skupine Ciclidae, od kojih je Orechromis niloticus bila najzastupljenija u ukupnom ulovu. Procjena produkcije je uspoređena s eksperimentalnim ulovom mrežama i potencijalnom procjenom prirasta upotrebom Morpho-Edaphic indeksa (MEI), kako su odredili Henderson i Welcomme.

Doprinos je napravljen i međusobnom usporedbom ribolovnih alata, a najčešće su korištene mreže sačmarice $(29 \%)$, zatim stajačice $(25 \%)$, udice i parangali $(16,6 \%)$, vrše $(16,6 \%)$ te povlačne mreže $(8,3 \%)$. Predložene su daljnje mjere gospodarenja.

Ključne riječi: jezero Gbedikere, produkcija, procjena ulova, ribari, ulov, prirast

\section{REFERENCES}

ADP (1995): Survey of Agricultural Developments Projects in Kogi State, Nigeria 186 p.

Apeloko, F., du Feu, T. A. (1995): Frame Survey, Kainji Lake National Institute for Freshwater fisheries Research (NIFER) Annual Report, 177-180.

APHA (1980): Standard methods for examination of water and waste water. $15^{\text {th }}$ ed. American Public Health Association, Washington D.C., 1134 p.
Bankole, N. O., Sule, O. D., Okwundu E. C., Umoru, I., Balogun. I. (1994): Preliminary investigation on the frame and Catch Assessment Survey of Alau Lake, Maiduguri, Borno State. N.I.F.F.R., Annual report, 134-147.

Bankole, N. O., Mbagwu, I. G. (2000): Aspects of the Fisheries of Alau Lake, Maiduguri ,BornoState, North Eastern Nigeria. African journal of tropical hydrobiology and fisheries, 1-2, 49-62.

Bazigos, G. P. (1972): Frame survey at Kanji Lake Nigeria FAO/UNDP/SF/NIR/24/ST.1.

Coulter, G. W. (1988): Production dynamics in Lake Tanganyika. In; Predator prey relationships, population dynamics and Fisheries productivity of large African Lakes (Ed. by D. Lewis). CIFA Occass, Pap. 15, 18-25.

Haruna, A. B., Abubakar, K. A., Ladu, B. M. B. (2006): An assessment of physico-chemical parameters and productivity status of Lake Geriyo, Yola, Adamawa state, Nigeria. Biological and Environmental Sciences Journal for the tropics, 3, 1, 18-23.

Henderson, H. F., Welcomme, R. C. (1974): The relationship of yield to morpho-edaphic Index and numbers of fishermen in African Inland Fisheries. FAO, Rome. CIFA Occassional Paper, $1,19 \mathrm{p}$.

Moses, B. S., Udoindiong, O. M., Okon, A. O. (2002): A statistical survey of the artisanal fisheries of south- eastern Nigeria and the influence of hydroclimatic factors on catch and resource productivity. Fisheries Research, 57, 267-278.

Ryder, R. A., Henderson, H. F. (1975): Estimates of potential Fish yield for Nasser Reservoir, Arab Republic of Egypt. Journal of the Fisheries Research Board of Canada, 32, ii, 2131-2157.

Schlesinger, D. A., Regier, H. A. (1982): Climatic and morphoedaphic indices of fish yields from natural lakes. Transactions of the American Fisheries Society, 111, 141-150.

Toews, D. R., Griffith, J. S. (1979): Empirical estimates of potential fish yield for the Lake Bangwelu system, Zambia, Central Africa. Transactions of the American Fisheries Society, 108, 241- 252. 